\title{
PRODUCTS LIABILITY IN THE CONFLICT OF LAWS-TOWARD A THEORY OF ENTERPRISE LIABILITY UNDER "FORESEEABLE AND INSURABLE LAWS": ॥*
}

\author{
ALBERT A. EHRENZWEIG†
}

IN my earlier Article, "Guest Statutes in the Conflict of Laws,"1 I attempted to show that the "place of wrong" rule offered by the Restatement of Conflicts for all types of torts, having been developed to protect the defendant against "punishment" under a law other than that of the place of his conduct, ${ }^{2}$ is quite inappropriate as a device for solving choice of law problems involving what I have called enterprise liabilities for negligence without fatth, and that one of these liabilities, the motorist's liability to his guest, should be subject to the "reasonably foreseeable and insurable" law. The present Article will examine the applicability of this principle in the growing field of products liability.

The development of the liability of manufacturers and other suppliers has often been described as the very model of the growth of a common-law institution. ${ }^{3}$ Notwithstanding the many and often painful stages of this development, the final result has been surprisingly uniform throughout the United States, and indeed in common-law jurisdictions generally. But there have remained a few important differences among the several jurisdictions, particularly with regard to the structure and scope of the strict liabilities for breach of warranty ${ }^{4}$ and the negligence liabilities under the so-called MacPherson rule, ${ }^{5}$ both generally ${ }^{6}$ and in cases involving food and drink. ${ }^{7}$ In view of the great practical importance and interstate impact of these problems, one might expect a considerable body of conflicts law. But notwithstanding much gratuitous judicial language, there is almost no such law, and the problem will be one of novel impression in most jurisdictions. Thus, no other topic in the conflicts law of torts lends itself more readily to the formulation of a rational

\footnotetext{
*The second of three Articles by the author. The first appears in the present volume at page 595. The third will appear in the May issue.

†Walter Perry Johnson Professor of Law, University of California (Berkelcy).

1. 69 YALE L.J. 595 (1960).

2. See American Banana Co. v. United Fruit Co., 213 U.S. 347, 356 (1909).

3. See, e.g., Levi, An Introduction to Legal Reasoning (1949). For a comparative study, see Comment, Retailer and Manufacturer Liability in Germany and the United States for Personal Injury From Defective Products, 1959 DuKE L.J. 94.

4. See Prosser, Torts 493-96 (2d ed. 1955); Prosser, The Assault Upon the Citadel (Article to be published in the Yale Law Journal for June 1960).

5. MacPherson v. Buick Motor Co., 217 N.Y. 382, 111 N.E. 1050 (1916); sce ProsSER, TORTS 499-501 (2d ed. 1955).

6. Id. at 502-06, 510-11.

7. Id. at 507-10.
} 
solution, unburdened by concepts and rules drawn from the dogmatic interlude in American legal history which produced the Restatement of the Lau' of the Conflict of Lawe, a document which, as to other topics, has so seriously disturbed the law in this field. ${ }^{8}$

Products liability is hardly older than that dogmatic interlude. No wonder then that, in the field of products liability ${ }^{9}$ perhaps even more than elsewhere, some courts ${ }^{10}$ have endeavored to give at least the semblance of reality to the Restaters' grand but lifeless design-by invoking their conflicts rules even in those cases in which there was no conflict. ${ }^{11}$ Such cases, which represent al-

8. See, e.g., Ehrenzweig, Contracts in the Confict of Laws-Part Onc: I"alidity, 59 Colums. L. Rev. 973 (1959); Ehrenzweig, The Statute of Frands in the Conflict of Lauts: The Basic Rule of Validation, 59 Colum. L. REv. 874 (1959); Ehrenzweig, Thic Place of Acting in Intentional Multistate Torts: Law and Reason Versis the Restutement, 36 Minn. L. Rev. 1 (1951). See generally Enrenzwerg, Confict of L.iws 6-13 (1959).

9. For purposes of this analysis, breach of warranty is treated as a tort, as it is fur other purposes in most jurisdictions. See Prosser, TorTs 493-94 (2d ed. 1955). See also Dickerson, Products Liability and the Food Consumer (1951); Prosser, The Implied Warranty of Merchantable Quality, 27 Mins. L. Rev. 117 (1943); Patterson, IIantfacturer's Statutory Warranty: Tort or Contract?, 10 MIERCER L. REv. 272 (1959); Prosser, The Assault Upon the Citadel (Article to be published in the Yale Low Journal for June 1960).

10. Pennsylvania, the home of the American Law Institute, author of the Reslafement, has with particular frequency invoked conflicts rules unnecessary to the decision. See Carpini v. Pittsburgh \& Weirton Bus Co., 216 F.2d 404 (3d Cir. 1954) (Pennsylvania brakes causing West Virginia bus accident) (Goodrich, J.); Tomso v. A. P. De Sanno \& Son, 209 F.2d 544 (3d Cir. 1954) ; Renuzit Home Prods. Co. v. General Mills, Inc., 207 F.2d 955 (3d Cir. 1953) ; cf. Ryan v. Adam Scheidt Brewing Co., 197 F.2d 614 (3d Cir. 1952) ; Kieffer v. Blue Seal Chem. Co., 196 F.2d 614, 615 (3d Cir. 1952) (Minnesota explosion of New Jersey product) (Goodrich, J.); Diesbourg v. Hazel-Atlas Glass Co., 176 F.2d 410 (3d Cir. 1949) (Florida resident injured by Ohio bottle, filled in New Jersey-MacPherson rule) (Goodrich, J.); Mannsz v. Macwhyte Co., 155 F.2d 445 (3d Cir. 1946) ; Smith v. Piper Aircraft Corp., 18 F.R.D. 169 (M.D. Pa 1955) (Alabama widow recovers from Pennsylvania manufacturer for death of husband lilled in Georgia accident under Georgia law identical with lex fori); Foley v. Pittsburgh-Des Mloines Co., $363 \mathrm{~Pa} .1$, 9-10, 29-33, 68 A.2d 517, 521-22, 530-32 (1949) (MacPherson applieable in both Ohio and Pennsylvania).

This practice is particularly objectionable when the court, lacking information on the lex loci, purports to find the lex loci in accord with the general law of torts in effeet at the forum. See Trowbridge v. Abrasive Co., 190 F.2d 825 (3d Cir. 1951) (presumed Oregon law), which, for its presumption of Oregon law, relied upon a "holding" in Mloran v. Pittsburgh-Des Moines Steel Co., 166 F.2d 90S, 916 (3d Cir. 1948) (presumed Ohio law).

For a similar regrettable practice in contracts cases, see Ehrenzweig, Contracts in the Conflict of Lawes-Part One: Validity, 59 Couvar. L. Rev. 973, 986 n.99 (1959). For persuasive criticism, see Milner, Restatement: The Failure of a Legal Experinsmi, 20 U. PITT. L. REv. 795, 799 (1959), with statistical analysis.

11. Alexander v. Nash-Kelvinator Corp., 261 F.2d 187 (2d Cir. 1958) (MacPhersuns in Pennsylvania and New York); Wright v. Carter Prods. Inc., 244 F.2d 53, 57, 59 (2d Cir. 1957) (Massachusetts and New York-MacPherson); Pierce v. Ford Mrotor Co., 190 F.2d 910 (4th Cir. 1951) (MacPherson in Delaware and Virginia); Anderson v. 
most all available case "law," may be disregarded in this study.12 In all of them the courts have in effect, and should have expressly, applied the lc.r fori in the absence of any other law "properly" claimed to be different and applicable. ${ }^{13}$

Linton, 178 F.2d 304, 309 (7th Cir. 1949) (holding for plaintiff under presumed "modern" Iowa rule in the absence of an unambiguous rule to the contrary in either Iowa or the forum); Reed \& Barton Corp. v. Maas, 73 F.2d 359 (1st Cir. 1934) (Massachusetts manufacturer of coffee urn held liable under Wisconsin law of plaintiff's residence, identical with federal pre-Erie le.x fori) ; State v. Garzell Plastics Indus., 152 F. Supp. 483 (E.D. Mich. 1957) (Maryland drowning owing to defect in Michigan boat-MacP/hcrson) ; Burkett v. Globe Indem. Co., 182 Miss. 423, 181 So. 316 (1938). In Gaston v. Wabash R.R., 322 S.W.2d 865 (Mo. 1959) ; Haberly v. Reardon Co., 319 S.W.21 859 (Mo. 1959) ; Atwell v. Pepsi-Cola Bottling Co., 152 A.2d 196 (D.C. Mun. Ct. App. 1959), the lex fori was probably the same as the lex loci, although the former was not mentioned. On Missouri law, see 24 Mo. L. Rev. 554 (1959).

Occasionally, the two laws might have reached a decision for the plaintiff in different ways. See, e.g., Sylvania Elec. Prods., Inc. v. Barker, 228 F.2d 842 (1st Cir. 1955), corl. denied, 350 U.S. 988 (1956), where a possibly less stringent liability rule under the law of Nebraska, the place of harm, was neutralized by a lex fori favoring plaintiff concerning the burden of proof. See also 228 F.2d at 850 n.4 (conflicts discussion "perhaps . . . academic").

Unfortunately, the Supreme Court of the United States, in one of the very few cases in which it had occasion to discuss products liability, announced, in erroneous sole reliance on the nonconflicts case of MacPherson, the conflicts rule that "commonly" "a person acting outside the state may be held responsible according to the law of the state for injurious consequences within it." Young v. Masci, 289 U.S. 253, 259 (1933). In MatPherson the domestic supplier rather than the foreign manufacturer was the defendiunt.

12. Only rarely will courts refrain from referring to the "rule" and base their decisions on a lex fori coinciding with all pertinent foreign laws. See, c.g., Dalchite $v$. United States, 346 U.S. 15, 53 (1953) (dissenting opinion); Alexander v. Inland Sted Co., 263 F.2d 314 (8th Cir. 1958); Hentschel v. Baby Bathinette Corp., 215 F.2d 102, 104-05 (2d Cir. 1954). For a list of cases in which conflicts problems might have been present but were ignored, see Page, Conflict of Law Problems in Automobile Accidcuts, 1943 WIs. L. Rev. 145, $168 \mathrm{n} .72$ (1943). In a series of articles I hope to show that cotrts in all countries and at all times, except for the current period of conceptualist deviation, have treated the le.x fori as the primarily applicable law. See Ehrenzweig, The Lex ForiThe Basic Rule in the Conflict of Laws (article to be published in the Michigan Laru Rivview for March 1960) ; Ehrenzweig, Lex Fori: Exception or Ruleq, 32 Rocky MT. L. Rev. 13 (1959). See also Currie, On the Displacement of the Law of the Forum, 58 CoLur. L. Rev. 964 (1958). A major exception to this thesis is the lex validitatis in the conflicts of law of contracts. See Ehrenzweig, The Statute of Fraids in the Conflict of Laws: The Basic Rule of Validation, 59 Couurs. L. Rev. 874 (1959); Ehrenzweig, Contracts in the Confict of Laws-Part One: Validity, 59 Colum. L. Rev. 973 (1959); Ehrenzweig, Contractual Capacity of Married Women and Infants in the Confict of Lazes, 43 Mrns. L. Rev. 899 (1959); Ehrenzweig, Releases of Concurrent Tortfeasors in the Conflict of Laws (article to be published in the Virginia Laze Revieze for May 1960).

13. All through this Article I shall use the phrase "a proper law" as designating any law having a contact with the case sufficient to displace the lex fori. See also Ehrenzweig, Contracts in the Conflict of Lazes-Part One: Validity, 59 CoLus. L. REv. 973 (1959). This usage is fundamentally different from that suggested by Professor Morris according to whom "the proper law" is the law primarily applicable. Morris, The Proper 
The tortured constructions and doctrinary convulsions to which courts are driven by their lipservice to the Restatement may be illustrated by two by-nomeans-isolated cases. In Rhode Island a manufacturer is liable to third parties for his defective products within the scope of the now almost universally accepted MacPherson rule. But a Rhode Island suit by the Mississippi user of a defective Rhode Island product was dismissed by the federal district court "reluctantly" following the "harsh rule" of Mississippi, ${ }^{14}$ which had refused to accept the MacPherson doctrine. The court felt compelled to do so because Mississippi was the "place of wrong." Historically at least, the primary, if not exclusive, rationale of this reference is, to use a phrase of Justice Holmes, that it is unjust for the forum to treat a defendant "according to its own notions rather than those of the place where he did the acts."15 It would have been difficult in the present case for the defendant to assert that he had observed a different standard of conduct or a different practice in pricing or insurance as to sales in Mississippi. No wonder that in order to do justice in the face of such hopelessly inadequate doctrine, Judge Magruder reversed the district court decision. But, adhering to the Restatcmesst rule, he had to talie refuge in a reconstruction of Mississippi law in the plaintiff's favor. ${ }^{10}$

In another case, a Missouri plaintiff, had been injured in an Indiana air crash, presumably caused by a defect of the airplane which had been manufactured and inadequately repaired in Kansas. Neither the court nor the parties were willing to investigate the clearly irrelevant law of Indiana and acquiesced in the application of the law of Kansas, the lc.x fori. But in order to do so, the court had to announce its own peculiar understanding of the $R e$ statement's place-of-wrong rule as designating the place "where the airplane was manufactured and repaired, rather than ... where the accident occurred."1i This, then, is the "certainty" of the Restatcment rule to which courts have been urged to sacrifice application of their own law.

Fortunately, among the thirty-odd cases purporting to apply the place-of-

Laze of a Tort, 64 HARv. L. Rev. 881 (1951). For a comparative study of American views, see De Nova, Rassegna della dotirina Anglo-Americance sui conffitti di leggi: 1940-1950, 2 Jus 251 (1950).

14. See Mason v. American Emery Wheel Works, 241 F.2d 906, $90 S$ (1st Cir.), cert. denied, 355 U.S. 815 (1957).

15. American Banana Co. v. United Fruit Co., 213 U.S. 347, 356 (1909). See also ALI, Treatise Accourpanying Restatearent of the LAw of Conflict of Laws, Draft No. 20-R, at 54 (1927), rejecting the English lex fori rule as "opposed to . . . an abrious requirement of justice, that a person may rely upon the law of the place where he acts or in which he causes events to happen ...." On Justice Holmes' private, more realistic, approach to conflicts law, see EHrenzweig, Conflict of LAws 11 n.18 (1959).

16. Mason v. American Emery Wheel Works, 241 F.2d 906 (1st Cir.), cert. dericd, 355 U.S. 815 (1957). It is doubtful if the holding correctly represented Mississippi law. See Rogers, Foreseeability in the Law of Negligence, 29 Mrss. L.J. 158 (1958); Comment, 26 U. CHI. L. REv. 653 n.5 (1959). On Rhode Island law, see S. C. Johnson \& Son, Inc. v. Palmieri, 260 F.2d 88 (1st Cir. 1958) ; Pastorelli v. Associated Eng'rs, Inc., 176 F. Supp. 159 (D.R.I. 1959).

17. Vrooman v. Beech Aircraft Corp., 183 F.2d 479, 480 (10th Cir. 1950). 
wrong rule, only two cases have been found in which application of a foreign law actually affected the result. Both involved an Ohio penal statute which, according to Ohio case law, has the effect of making the seller of defective food products liable without proof of negligence. In the first case, decided by the Second Circuit, ${ }^{18}$ an Ohio plaintiff recovered under the Ohio statute against a New York distributor of contaminated beef, because plaintiff's deceased "ate the food, took sick and died" in Ohio. The fact that defendant's conduct took place in New York did "not oust the law of Ohio." In the second case, a lower court in Missouri reached a similar result, following the Second Circuit decision. ${ }^{19}$

While there can be little quarrel with the result of these two cases, their dogmatic reasoning could fatally confuse the nascent conflicts law of products liability. To take two extreme situations: An Ohio citizen, on a trip to New York, consumes, and falls ill from, contaminated food produced and sold by an Ohio manufacturer in violation of the Ohio statute. Under the Restatoment "rule," apparently sanctioned by the courts in the two above mentioned cases, he would not be able to recover under the Ohio statute because the harm occurred in New York. Or an Italian citizen, on a trip through Ohio, consumes, and falls ill from, contaminated food produced and sold to him in Italy. Under the Restatement "rule" he could recover from the Italian manufacturer under Ohio law in any state in which he could obtain jurisdiction. The basis for distinguishing these situations from those properly subjected to the law of the place of harm must be found in the rationale of products liability itself.

In a much-quoted concurring opinion in Escola v. Coca Cola Bottling Co., ${ }^{20}$ Justice Traynor would have based this liability partially on the fact that "the risk of injury can be insured by the manufacturer and distributed among the public as a cost of doing business."21 While this proposition probably does not reflect present law in any jurisdiction, it admirably expresses what may well

18. Hunter v. Derby Foods, Inc., 110 F.2d 970 (2d Cir. 1940).

19. Hughes Provision Co. v. La Mear Poultry \& Egg Co., 242 S.W.2d 285 (Mo. Ct. App. 1951) (Ohio retailer permitted to recover under Ohio statute from Missoturi supplier). Application of the lex fori might have produced the same result. See 24 Mo. L. REv. 554 (1959).

2 Rabes, Conflict of Laws 319 (1947), relying on Hancock, TORTS in the ConFLICT of Laws 254 (1942), also cites Reed \& Barton Corp. v. Maas, 73 F.2d 359 (1st Cir. 1934), for the proposition that the locality to which the defendant's operations are dirccted is the material one for conflicts purposes. But in that case the court expressly stressed the identity of the pre-Erie federal law otherwise possibly applicable.

20. 24 Cal. $2 \mathrm{~d} 453,150$ P.2d 436 (1944). In Burgess v. Montgomery Ward \& Co., 264 F.2d 495 (10th Cir. 1959), lack of a modern rationale led to decision for defendant distributor in a suit by a seriously injured user of a ladder which broke when first extended. The court reasoned that defendant was not "obliged to test this ladder for structural strength," any more than "the operator of every retail store in the villages which dot the Kansas prairies." Id. at 498. That may be so. But, in contrast to the village retailer and the consumer, a national chain store 'is obligated and able to insure against losses caused by its operations.

21. $24 \mathrm{Cal} .2 \mathrm{~d}$ at 462,150 P.2d at 441 . 
become the prevailing rationale of products liability and thus properly usable as the basis of conflicts law: the supplier's broadening liability to both his buyer and third parties is both bearable and needed primarily because it serves the distribution of objectively, and usually subjectively, unavoidable loss and is, therefore, calculable in the process of pricing and insuring. ${ }^{22}$ For intrastate purposes, the basis of such calculation is, of course, the supplier's own law. Where, however, distribution in sister states as well as abroad is contemplated or at least foreseeable, the possible impact of laws prevailing in the states or countries of such distribution must and can be taken into account. ${ }^{23}$ No reason is apparent why in such cases the manufacturer should be given the benefit of a more lenient law.

22. This position is widely held. See N.Y. Law Revision Comm'n, Products Liability for Breach of Warranty and Negligence, N.Y. LEG. Doc No. 65, at 417 (1943); Enresizweig, Negligence'Without Fault (1951); Ehrenzweig, Assurance Oblige-A Comparative Study, 15 Law \& Contearp. Proв. 445 (1950); Feezer, Monufacturcr's Liability for Injuries Caused by His Products: Defective Automobiles, 37 MICE. L. REv. 1, 24 (1938); Green, Should the Mantufacturer of General Products Be Liable II'itlont Negligence?, 24 TENN. L. REv. 928 (.1957); Gregory, Trespass to Negligence to Absolute Liability, 37 VA. L. Rev. 359, 384 (1951); James, General Prodıcts-Should Iromufacturers Be Liable Without Negligence?, 24 TENN. L. REv. 923 (1957); James, Prodiscts Liability, 34 Texas L. REv. 192 (1955); James, Accident Liability Reconsidercd: The Impact of Liability Insurance, 57 YAIE I.J. 549 (1948); Llewellyn, On Warronly of Quality, and Society, 36 CoLurr. L. REv. 699, 704 n.14 (1936). But see Cooperrider, A Comment on the Law of Torts, 56 MIICE. L. REv. 1291, 1305 (1958); Plant, Strict Liability of Manufacturers for Injuries Caused by Defects in Products: An Opposing Vicw, 24 TENn. L. Rev. 938 (1957). For intermediate positions, see Lucey, Liability Writhout Fault and the Natural Law, 24 TENN. L. REv. 952 (1957); Noel, Manufacturers of Products-The Drift Toward Strict Liability, 24 TENN. L. Rev. 963 (1957); Wilson, Products Liability, 43 CALIF. L. REv. 809 (1955). See generally Symposium: Adzartised-Product Liability, 8 CLev.-Mar. L. Rev. 1 (1959).

23. See Ehrenzweig, The Place of Acting in Intentional dfultistate Torts: Law and Reason Versus the Restatement, 36 MIrNs. L. REv. 1, 19 (1951); cf. Shuman \& Prevezer, Torts in English and American Conflict of Laws: The Role of the Forum, 56 Mricu. I. REv. 1067, 1113 (1958).

Conceivably, an American manufacturer relying on the lenient liability laws of his own state may seek to limit distribution of his product to that state. If such a scheme were devised bona fide, as for example to make possible hazardous but socially desirable experiments, and if sufficient precautions were taken to warn out-of-state users, there could be situations in which application of a foreign law of liability would be inappropriate under the test here proposed. A similar situation could arise with regard to extranational products of a foreign manufacturer subjected to transient jurisdiction in this country. But such situations would be rare. Since the foreign manufacturer can generally be subject to the jurisdiction of a court in this country only if he is doing business here, problem cases would be limited to those where he has expressly excluded distribution in this country of a particular product. Current products liability insurance policies are usually limited to accidents within the United States, its territories and possessions and Canada. Arnold, Products Liability Insurance, 1957 WIs. L. REv. 429, 440. Here again interstate and international conflicts may require different treatment. EnREvizwerg, Co:iFLICT of Laws 17-22 (1959). See also 2 Rabei, Conflict of Laws 319-20 (1947). For a case in which the manufacturer sought to avoid the multiple impact of liability and liti- 
In general, plaintiff will be able to obtain application of the most favorable law by choosing his forum in the expectation that the court will, in accordance with the basic rule, ${ }^{24}$ apply its own law. This rule alone may ultimately suffice once the judicial and legislative reform of our law of jurisdiction has, on the one hand, put at the plaintiff's disposal all "convenient fora" including that of his residence and, on the other hand, protected the defendant against being "caught" in an inconvenient forum. ${ }^{25}$ But until the conclusion of this development, the forum may have to choose relevant foreign laws over its own. For the protection of the plaintiff, Walter Wheeler Cook in 1942 suggested that the plaintiff be given the choice of the law most favorable to him. ${ }^{20}$ Limited to foreseeable and thus "insurable" laws, this postulate is, in effect, operative today, in keeping with the growing tendency of American courts to protect the consumer. In all cases in which the conflicts question was pertinent, the decision was for the plaintiff. ${ }^{27}$

gation by an agreement with the foreign distributor, see George Monro, Ltd. v. American Cyanamid \& Chem. Corp., [.1944] K.B. 432 (C.A.).

Some support for the suggested test might be derived from the leading case of Hunter v. Derby Foods, Inc., 110 F.2d 970, 972 (2d Cir. 1940), where the court stressed the fact that defendant had "sent food into Ohio ...." The same factor appears in the peculiat analogies referred to by the court: "that of shooting a firearm across the state line, ... or owning a vicious animal which strays over the line." Ibid. In all such cases the foreign impact is at least foreseeable.

24. See Ehrenzweig, The Lex Fori-The Basic Rule in the Conflict of Laws (article to be published in the Michigan Laze Review for March 1960).

25. See Ehrenzweig, The Transient Rule of Personal Jurisdiction: The "Pouver" Myth and Forum Conveniens, 65 YALE L.J. 289 (1956).

26. Cook, The Logical and Legal Bases of the Conflict of Laws 345 (1942): "After all, the defendant did act for his own purposes, and his act caused the damage; if the domestic rule of one of the states would impose liability if all had happened there, why not allow the recovery?" Cook did not see this postulate endangered by ccrtain older decisions of the United States Supreme Court which were based on obsolete "notions about the necessary territorial limitations upon "law." Id. at 40 n.75.

27. Cases in which the plaintiff lost, when analyzed, reveal either that no conflict was present, or that the court was advised of no conflict, or viewed the conflicts question as irrelevant. See Mannsz v. Macwhyte Co., 155 F.2d 445 (3d Cir. 1946) (recovery denicd under law of Pennsylvania, state of forum and harm; no law more favorable to plaintiff mentioned) ; Brooks v. Hill-Shaw Co., 117 F.2d 682, 685 (7th Cir. 1941) (conflict irrelcvant) ; Page v. Cameron Iron Works, 155 F. Supp. 283, 288 (S.D. Tex. 1957) (conflict irrelevant) (semble) ; Minrose Hat Co. v. Gabriel, 149 F. Supp. 908 (D.N.J. 1957) (law of the place of manufacture and that of the forum (and harm) both denied applicability of res ipsa loquitur in view of defendant's "explanation") ; Saena v. Zenith Optical Co., 135 W. Va. 795, 65 S.E.2d 205 (1951) (no conflict). In Poplar v. Bourjois, Inc., 298 N.Y. 62,80 N.E.2d 334 (1948), a negligence suit against a perfume manufacturer was dismissed under the law of Maryland, the state of the plaintiff's place of injury. But the narrow interpretation of the MacPherson rule in New York, the forum and presumably state of manufacture, would apparently have led to the same result. See Prosser, Tonts $500 \&$ nn.31, 37 (2d ed. 1955). Cases barring the suit under the forum or foreign statute of limitations are not pertinent. E.g., Maryland v. Eis Automotive Corp., 145 F. Supp. 444 (D. Conn. 1956) ; McGrath v. Helena Rubenstein, Inc., 29 F. Supp. 822 (S.D.N.Y. 1939). Nor are decisions concerning jurisdiction. E.g., Openbrier v. General Mills, Inc., $340 \mathrm{~Pa} .167,16$ A.2d 379 (1940). 
To be sure, this rule might occasionally enable the plaintiff to recover against a foreign supplier under the latter's law where he would fail to recover against a domestic defendant. But this concededly undesirable result merely reflects the equally undesirable, but unavoidable, fact that any scheme for the distribution of losses caused by nationwide mass distribution is, and will probably continue to be, based on the supplier's rather than on the consumer's calculation. While the latter cannot be realistically expected to arrange his program of insurance and consumption to accord with the liability laws of each state whose products he may consume, the producer can be expected to calculate his losses under the laws of each state in which his products may be distributed, and thus to carry the burden of the most unfavorable law among those reasonably foreseeable and insurable.

The defendant, under our present law of jurisdiction, must be permitted, however, to object to the application of a nonforeseeable and thus uninsurable law in a "transient" forum. The most important limitation on the lex fori in this respect is one analogous to that discussed in my earlier Article on "Guest Statutes in the Conflict of Laws."28 The guest boarding an automobile in the state where it is permanently kept may expect only as much protection as is given to him by the law of that state, and if that law contains a so-called guest statute limiting his host's liability to wilful negligence, this liability is all the guest should be allowed to count on wherever he may be injured. It seems unreasonable to compel the host, as we do now, to buy insurance against a liability that he might incur under the law of a state possibly to be reached on a yet unplanned out-of-state trip. On the other hand, the guest can be expected to be familiar with the guest statute of his host's state and to carry his own accident insurance without regard to more favorable laws prevailing in his own state or in states he might touch on his trip. This situation is of course absent in the typical products liability case. The average consumer cannot realistically be expected to carry the accident or health insurance he needs even under the products liability laws of his home state. On the other hand, insurance for liabilities incurred under the consumer's law can reasonably be carried by the manufacturer who expects distribution of his product in the consumer's state.

This conclusion may be different where the buyer is an entrepreneur himself, as for instance, a builder or department chain store who purchases materials from manufacturers or wholesalers all over the country. Such a buyer may himself be expected to foresee and calculate the incidents of his operations. ${ }^{29}$ To be sure, in such cases the most appropriate allocation of the burden to insure will often be doubtful, and, owing to our present highly uncertain conflicts law, insurance practice lacks a reasonable pattern. But once the courts

28. 69 Y ALE L.J. 595 (1960).

29. Prosser, TORTS 506 (2d ed. 1955), points out this difference, citing Note, 37 Colunr. L. Rev. 77 (1937). See also Plant, Strict Liability of Mfamufacturers for Injuries Caused by Defects in Products-An Opposing View, 24 TENs. L. Rev. 938, 946 (1957); Ehrenzwetg, Negligence Without Fault (1951). 
have imposed liabilities based on such an allocation, however arbitrary, insurance practice will follow. ${ }^{30}$ Whether the manufacturer or another supplier be held liable, whether the forum adhere to a fault concept of products liability or to a limitation of this liability to the immediate purchaser, and whether it favor the wider distribution of risks and losses in any or all respects, any court should accept the application of proper laws typically calculable in the particular enterprise. In this sense enterprise liability will, in the conflicts context, also, "extend to all casualties and hazards that are injected into society by the activity of the enterprise, at least to the extent that they are reasonably foreseeable." 31

In the absence of conclusive rulings on the subject, it seems permissible, and indeed imperative, to formulate postulates which can now be adopted by the courts without abandonment of accepted terminology, and which respond to economic and social needs as well as to sound theory. ${ }^{32}$ In summarizing these postulates, a distinction must be drawn according to whether the parties in the particular case have the benefit of a modern law of jurisdiction or must adjust their needs to the catch-as-catch-can (transient) rule still prevailing to some extent in some states, under which the forum may well lack the desirable contact-based competency. ${ }^{33}$

First, the lex fori applies prima facie, in accordance with the basic rule of tort conflicts law and the practical exigencies of products liability in particular.

Second, the modern law of personal jurisdiction now permits in some states, and will no doubt soon permit more generally, suit in virtually any state that has at least one of a growing number of contacts with the case. Among those,

30. Such liabilities, with their multiple impact on manufacturers, wholesalers and retailers, are, however, hardly suited to offer final solutions. Ultimately, these concurrent liabilities and liability conflicts as well as liability insurance will have to yield to a schemc insuring losses where they occur. See generally EhrEnzweig, "Full Aid" Insurance FOR the Traffic Victis (1954) (with domestic and foreign models); Grein, Traficic Victims, Torts Law and Insurance (1958); Feldman, Liability of Manufachurers of Home Furnishings for Harm Done by the Product, 1955 Ins. L.J. 519; Ehrenzweig, Book Review, 11 Stan. L. Rev. 400 (1959).

31. James, General Products-Should Manufacturers Be Liable Without Negligence?, 24 Tenn. L. Rev. 923, 927 (1957).

32. Owing to the ubiquity of possible harm caused by the production of atomic energy, adoption of conflicts rules based on similar principles seems imperative although limitation of maximum recoveries, preferably by a scheme of loss insurance, will be inevitable. See, e.g., Boisserée, Fragen des interlokalen ind internationalen Privalrcchls bei der Haftung fïr Schäden dutrch Atomanlagen, 11 NEUE JURISTISCHE Wochenschintr 849 (1958). See also Seavey, Torts and Atoms, 46 Calif. L. REv. 3, 11 (1958), suggesting federal legislation as the only remedy. See generally Ehrenzweig, The Atom and the Lane of Torts, $A$ Begiming and an End, in Volume in HoNor of Professor WaGatsuma 16 (1958); Murphy, Atomic Energy and the Law: A Bibliography, 12 VAND. L. REv. 229 (1958); Atomic Industrial Forum, International Problems of Financting Protection Against Nuclear Risk (1959).

33. See generally Ehrenzwetg, Confuict of Laws 102-06, 120-25 (1959). 
in addition to the defendant's domicile, the "place of wrong" will usually be included. It is likely that further progress will lead to the treatment of plaintiff's residence as the place of wrong for the purpose of creating a proper forum. ${ }^{34}$ Under this system, the plaintiff would usually be able to choose from among several courts that with the most favorable law. Whether the parties' unequal economic status in the typical products liability case will induce the courts to relieve the plaintiff of the burden of a foreign law suit by permitting him to claim a more favorable foreign law even at the place of his own residence remains to be seen.

In any event, in those cases in which defendant, owing to peculiar conditions of his business, ${ }^{35}$ will feel justly aggrieved at having his liability treated under a noninsurable lex fori the doctrine of forum non conveniens will have to supply the necessary corrective. ${ }^{36}$ Once the state of the plaintiff's residence has become more widely available to the latter, the defendant will probably more generally be permitted to resort to this doctrine to prevent suit in a then largely unnecessary transient forum. In the federal courts transfer of such cases to the more convenient forum should not be permitted to preclude application of the more proper lex fori of the transferee court. ${ }^{37}$

Finally, choice of law will remain generally necessary in those states in which, in the absence of a machinery assuring a contact-based jurisdiction, the plaintiff or the defendant may still be forced into an improper forum and thus subjected to an "improper" lex fori. In such cases the plaintiff must be permitted to claim applicability of any "proper" law-usually that of the defendant's place of business or of the plaintiff's residence. The defendant, on the other hand, must be permitted to object to the application of any lex fori which is not reasonably foreseeable and insurable. ${ }^{38}$

34. Compare Shuman \& Prevezer, supra note 23, at 1107, suggesting that the place of harm in certain unique situations should be "where the plaintiff is unable to support his family or to continue his work . . or may become a public responsibility ...."

35. See note 23 supra.

36. Considerations of this kind may have induced the English court in George Afonro, Ltd. v. American Cyanamid \& Chem. Corp., [1944] K.B. 432 (C.A.), to decline jurisdiction in a subrogation suit by an English distributor against an American manufacturer who, "with the consent of the plaintiffs, [had sought carefully] to keep all claims against them within the exclusive jurisdiction of the courts of the United States." Id. at 43S.

37. See Currie, Change of Venue and the Confict of Lowes, 22 U. CEI. L. REv. 405, $459-70$ (1955).

38. The law of a transient forum as such is probably not a foreseeable law in this sense. Thus a supplier operating in a state with a lenient liability law should probably be entitled to rely in his calculations on the incidence of losses occurring in states with similar lenient laws notwithstanding the possibility that plaintiffs from these states might sue in third states by obtaining transient jurisdiction. 


\section{THE YALE LAW JOURNAL}

Volume 69 APRIL 1960 NUMBER 5

\section{Alan Appelbaum \\ Editor-in-Chief}

JaMES M. EDWARDS

Stephen ManN

Donald G. Marshall

ROBERT L. WEINBERG

Note \& Cormment

Editors
James McC. Jounstone

Gilbert Paul. Vernit Article \& Book Review Editors

EUGENE I. LAMBERT Managing o Case Editor
David Albenda

Neale M. Albert

Hershet Y. AlLERHANd

Steven D. Anderman

Hurd Baruch

ARTHUR J. Berk

Thomas B. Bracken

Carroll W. Brewster

George B. Driesen

Eliezer EREII

Davm R. Evans

David I. Goldblatt

Harrison J. Goldin
Stuart B. Goldoman

Lawrence G. Goodman

William S. Greenawalt

Richard S. Harrison

Benjamin T. Hopkins, II

Robert E. Hudec

Robert A. JoHNSON

ARoN Katz

Lawrence P. KLaMron

ZANE KLEIN

Alan H. Molod

Bruce Montgomery

Samuel Myers
J. Alexander Onderdonk

Alan D. PEKelner

STODdARd D. PlatT

David A. Rosen

Herbert Schreider

Richard Lauder Sutton

Peter R. TAft

David M. Thunek

Adar Walinsky

Herbert S. WANDER

DONALd P. WeFER

SidNey M. WOLINSKY

Jere A. Young

MARIE McMaeton

Business Secretary

\section{CONTRIBUTORS TO THIS ISSUE}

Curtis J. Berger. A.B. 1948, University of Rochester; LL.B. 1951, Yale University. Member of New York Bar. Instructor in Law, Yale Law School, 1959-1960; Graduate Fellow, Yale Law School, Fall 1958, Spring 1960.

Albert A. Ehrenzwerg. Dr. Jur. 1928, University of Vienna; J.D. 1941, University of Chicago; LL.M. 1942, J.S.D. 1952, Columbia University. Member of the New York Bar. Walter Perry Johnson Professor of Law, University of California, Berkeley. 